\title{
The Intrinsic Rhythmicity of Spike-Burst Generation in Pancreatic $\beta$-Cells and Intercellular Interaction within an Islet
}

\author{
Hiroshi KItasato, Rihei Kal', Wei-Guang Ding, and Mariko Omatsu-Kanbe \\ Department of Physiology, Shiga University of Medical Science, Ohtsu, 520-21 Japan
}

Key words: $\quad$ pancreatic $\beta$-cell, electrical activity, glucose metabolism, $\mathrm{NAD}(\mathrm{P}) \mathrm{H}$.

\section{$\mathrm{P}$} Pancreatic $\beta$-cells display cyclic spike-burst activity in response to extracellular glucose of intermediate concentrations $(8-15 \mathrm{~mm})$. The spike-burst duration varies with the change in glucose concentration. Insulin release from $\beta$-cells is closely related to an increase in intracellular $\mathrm{Ca}^{2+}[1]$, which is mainly due to $\mathrm{Ca}^{2+}$ influx during spiking activity [2-4]. Thus, spike generation plays a central role in the regulation of insulin release.

The discovery of ATP-sensitive $\mathrm{K}^{+}$channels $\left(\mathrm{K}_{(\mathrm{ATP})}\right)$ [5] contributed a great deal to understanding the mechanism underlying the electrical activity in $\beta$ cells. $\beta$-cells are furnished with a low-affinity glucose transporter, GLUT-2 $[6,7]$. The elevation of extracellular glucose concentration causes an increase in oxygen consumption [8, 9]. Although it is well established that glucose induces closure of the $\mathrm{K}_{\text {(ATP) }}$ channels, which leads to the depolarization underlying spike generation, termination of the spiking activity is not fully elucidated. The activation of $\mathrm{Ca}^{2+}$-activated $\mathrm{K}^{+}$channels $\left(\mathrm{K}_{(\mathrm{Ca}, \mathrm{V})}\right)$ was once postulated to be a decisive factor to terminate sustained spike firing [10, 11]. However, patch-clamp and pharmacological observations ruled out such a possibility on the basis that no $\mathrm{K}_{(\mathrm{Ca}, \mathrm{V})}$ channel was activated in the physiological range of $\mathrm{Ca}^{2+}$ concentration [12], and charybdotoxin, a specific blocker of $\mathrm{K}_{(\mathrm{Ca}, \mathrm{V})}$ channels, did not cause any change in electrical activity [13]. Intracellular $\mathrm{Ca}^{2+}$ measurements $[3,14,15]$ failed to show any direct contribution of intracellular $\mathrm{Ca}^{2+}$ in terminating the spiking period.

An alternative model, that slowly inactivating the $\mathrm{Ca}^{2+}$ current contributes to the termination of spiking activity, has been proposed from the similarity in burst patterns that is seen in certain molluscan and mammalian neurons [16]. In addition to this view, recently, two views are proposed from different laboratories. One is that the bursting pattern may be mediated by a distinct $\mathrm{Ca}^{2+}$-dependent $\mathrm{K}^{+}$channel or a slow $\mathrm{Ca}^{2+}$ dependent inactivation process of the $\mathrm{Ca}^{2+}$ current [17], and the other is that the depletion of endoplasmic reticulum $\mathrm{Ca}^{2+}$ deposits results in the activation of an inward current [18] while filling $\mathrm{Ca}^{2+}$ deposits with $\mathrm{Ca}^{2+}$ causes termination of the sustained depolarization underlying spiking activity.

In this short article, new experimental data are reviewed and an attempt is made to integrate them into a hypothesis for the regulation of complex electrical activity and insulin release.

\section{General Features of Electrical Activity of the Pancreatic $\beta$-Cell and $\mathrm{Ca}^{2+}$ Oscillation}

The electrical characteristics of pancreatic $\beta$-cells have been reviewed [19-21]. In brief, the most important findings for building a comprehensive view will be described first. The resting potential for low glucose (lower than $3 \mathrm{~mm}$; which is a subthreshold level for insulin release in most species of animals) is between -60 and $-70 \mathrm{mV}$ (Fig. 1). Upon raising the glucose level from the subthreshold level to $8-15 \mathrm{mM}$, the membrane potential slowly moves to a threshold potential of about $-50 \mathrm{mV}$. When this threshold is reached, rapid depolarization proceeds to a plateau potential (about $-40 \mathrm{mV}$ ) from which spikes are elicited (the initial spike-train). After sometime, the spiking

Received on August 22, 1996

Correspondence should be addressed to: Hiroshi Kitasato, Department of Physiology, Shiga University of Medical Science, Ohtsu, 520-21 Japan. Tel: +81-775-48-2151, Fax: +81-775-43-1960, E-mail: kitasato@belle.shiga-med.ac.jp

1 Li-Ping HE 


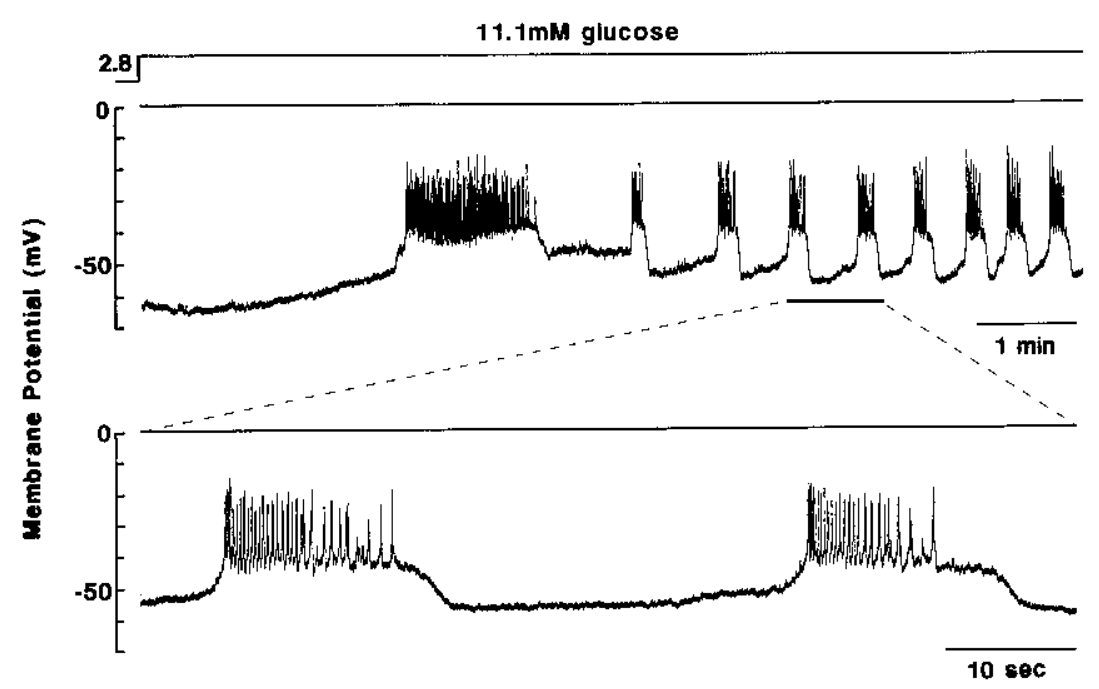

Fig. 1. Electrical response of the pancreatic $\boldsymbol{\beta}$-cell to glucose. The mouse pancreatic islet was perifused with a KrebsRinger-bicarbonate (KRB) solution $(\mathrm{pH}$ 7.4). Membrane potential was recorded by a high-resistance microelectrode from a cell in an islet. Glucose concentration was changed from 2.8 to $11.1 \mathrm{~mm}$. Lower trace shows the details of the portion denoted by a bar in the upper trace in 10-fold expanded time scale. Temperature was $36^{\circ} \mathrm{C}$. $\mathrm{Ca}^{2+}$ concentration in the KRB solution was $2.5 \mathrm{~mm}$. activity stops, and the membrane potential returns to the partially repolarized level. Then the membrane potential starts to oscillate regularly between the partially hyperpolarized level and the plateau potential on which the spikes are superimposed (Fig. 1). The spike frequency is about $10-12 \mathrm{~Hz}$ at the onset of spikeburst, but gradually decreases and sometimes incomplete spikes appear in the final stage of the spikeburst period. The crest of spikes varies between -20 and $-15 \mathrm{mV}$. This value is much lower than the equilibrium potential of $\mathrm{Ca}^{2+}\left(E_{\mathrm{Ca}} \approx 110 \mathrm{mV}\right)$. As the glucose level is elevated, the duration of the spike-burst period (the active phase) becomes longer, while the inter-burst interval (the silent phase) becomes shorter. At higher levels of glucose $(20-30 \mathrm{mM})$, the silent phase vanishes completely and spiking is continuous. Although the duration of the active phase is a function of extracellular glucose concentration [22], spike frequencies in the active phase are not dependent on the glucose level.

Intracellular $\mathrm{Ca}^{2+}$ concentration, $\left[\mathrm{Ca}^{2+}\right]_{\mathrm{i}}$, can be measured by microfluorometry using a fura- $2 \mathrm{Ca}^{2+}$ sensitive fluorescent probe [23]. When extracellular glucose is increased from the subthreshold level to about $10 \mathrm{~mm}$, intracellular $\mathrm{Ca}^{2+}$ abruptly increases after a small transient decrease, and its elevated level oscillates [3]. Simultaneous recordings of membrane potential and fura-2 fluorescence clearly demonstrated that the phase of $\mathrm{Ca}^{2+}$ oscillation was in accordance with the electrical bursting activity [2]. The removal of extracellular $\mathrm{Ca}^{2+}$ resulted in a fall in the intracellular $\mathrm{Ca}^{2+}$ level [24]. These observations are considered to be strong evidence supporting the view that an increase in $\mathrm{Ca}^{2+}$ influx directly causes elevation at the intracellular $\mathrm{Ca}^{2+}$ level, which is obligatory for the exocytosis of insulin release.
The electrical responses of $\beta$-cells to a sudden increase in extracellular glucose consist of an initial spike-train and subsequent cyclic spike-bursts. From the viewpoint of rhythmicity, firstly, the cyclic spikeburst activity will be reviewed. Secondly, we will discuss the initial spike-train in connection with the glucose metabolism on the basis of recent experimental results which may be relevant to the biphasic pattern of insulin secretion response.

\section{Termination of the Active Phase}

\section{Background inward and outward ionic currents}

In advance of reviewing recent experimental results regarding the termination of depolarization underlying spiking activity, we have to recall the results of experiments carried out about 20 years ago. In those experiments, the electrical membrane resistance was lowest at the beginning of the silent phase, and then gradually increased to a level about twofold of the lowest value $[11,25]$. In parallel with the membrane potential jump from the threshold potential to the plateau potential, the membrane resistance decreased drastically, indicating openings of voltage-dependent channels for inward currents. In contrast to a reliable estimation of membrane resistance during the silent phase, there is difficulty in assessing the membrane resistance from the magnitudes of membrane potential displacement induced by passing inward current pulses of constant magnitude during the active phase because voltage-gated channels are rapidly deactivated by the induced hyperpolarization. To overcome this difficulty, Smith et al. [26] conducted perforatedpatch whole-cell voltage clamp experiments in cultured single cells. They reported that, at $0 \mathrm{~mm}$ glucose, the resting input conductance was $5.1 \pm 0.9 \mathrm{nS}$ and that 
$8 \mathrm{~mm}$ glucose decreased the conductance by $80 \%$. Furthermore, they concluded there was no difference in the conductance measured during the plateau when compared to that during the silent phase, showing that an increase in $\mathrm{K}^{+}$conductance is not likely during termination of the active phase. Unfortunately, because of technical difficulty, the time course of the conductance change in both silent and active phases was not given in their experiments.

The model in which an increase in $\mathrm{K}^{+}$conductance terminates the plateau potential implicitly assumes the presence of a steady background inward current, while the alternative model, in which inactivation of the background inward current causes a termination of the plateau, implicitly presupposes a steady background outward $\mathrm{K}^{+}$current.

\section{Regenerative nature of repolarization}

The spike-burst rhythm can be reset by prematurely applying depolarizing current above the threshold, while supra-threshold hyperpolarizing current applied during the active phase triggers regenerative repolarization [27]. $\beta$-cells possess voltage-gated $\mathrm{Ca}^{2+}$ channels. The $\mathrm{Ca}^{2+}$ currents have been characterized in neonatal rat $\beta$-cells [28], insulin-secreting cell lines [29], and adult mouse $\beta$-cells [30-32]. Rapidly activating $\mathrm{Ca}^{2+}$ currents are inactivated in a $\mathrm{Ca}^{2+}$-dependent manner [29, 33], while slow inactivation $(\tau \approx 2.75 \mathrm{~s}$ at $0 \mathrm{mV})$ is $\mathrm{Ca}^{2+}$-independent [31]. Slow inactivation of the $\mathrm{Ca}^{2+}$ currents is proposed to be responsible for sustaining plateau potential [16]. This model seems to be able to describe fully the ionic basis of the plateau potential. However, there are some disagreements between the theoretical spike-burst computed on the basis of slowly inactivated $\mathrm{Ca}^{2+}$ current [34] and actual records. The most prominent discrepancy between them is that the theoretical curve shows progressive elevation of the spike threshold on the plateau potential while actual records show a rather slow fall in the spike threshold after transient elevation during the active phase. Furthermore, if inactivation of the inward current is a time-dependent event, the channel must become inactivated sometime after a long period of depolarization. If the inactivation of $\mathrm{Ca}^{2+}$ channels is the sole factor inducing repolarization, the plateau potential should always be interrupted by repolarization whenever the extracellular glucose concentration is high. However, in reality, at high concentrations of glucose $(20-30 \mathrm{~mm})$, the interburst silent phases are completely eclipsed and spiking is continuous. The discrepancy between the actual records and theoretically computed curves implies that factors other than the slow inactivation of $\mathrm{Ca}^{2+}$ channels may play a key role in triggering repolarization of the plateau.

The regenerative nature of repolarization requires the presence of a residual fraction of background inward current channels which will be deactivated in the process of repolarization. The magnitude of the background inward current can be assessed from the slope of the membrane potential change $(\mathrm{d} V / \mathrm{d} t)$. It should be noted that the maximum slope of regenerative repolarization is usually less in absolute magnitude than the slope of the regenerative depolarization that triggers spike-burst, indicating the ionic membrane current at the phase of regenerative repolarization is less than the current at the phase of regenerative depolarization. When the plateau potential is attained, the background inward current is almost equal to the background outward $\mathrm{K}^{+}$current. During the process of regenerative repolarization, the voltage-gated $\mathrm{Ca}^{2+}$ channel current may become zero (i.e., the maximum ionic membrane current may correspond to the background $\mathrm{Ca}^{2+}$ current which has been inactivated) unless the $\mathrm{K}^{+}$current increases. The fact that the ionic membrane current during regenerative repolarization is smaller in amplitude than that during regenerative depolarization raises the difficulty of detecting the background $\mathrm{Ca}^{2+}$ current using the conventional whole-cell clamp technique.

\section{What is the trigger of the regenerative re- polarization?}

To induce regenerative repolarization, the triggering of repolarization is necessary. The triggering of repolarization can be caused by either a decrease in $\mathrm{Ca}^{2+}$ conductance or an increase in $\mathrm{K}^{+}$conductance. Sulfonylurea (tolbutamide, glybenclamide, or glyburide) specifically inhibits the opening of $\mathrm{K}_{\text {(ATP) }}$ channels [35-37] and causes continuous spiking activity at intermediate concentrations of glucose. There is substantial evidence that the sulfonylurea receptor could be an integral component of the ATP-sensitive $\mathrm{K}^{+}$ channel in $\beta$-cells [38-40]. These observations suggest that opening the $\mathrm{K}_{\text {(ATP) }}$ channels is indispensable for triggering regenerative repolarization.

Raising extracellular $\mathrm{Ca}^{2+}$ to $10 \mathrm{mM}$ shortens the duration of the spike-burst in mouse $\beta$-cells perifused with a medium containing $15 \mathrm{~mm}$ glucose, and restores rhythmic spike-burst activity when continuous spike activity was induced by $30 \mathrm{~mm}$ glucose. On the basis of these observations, Henquin [22] has suggested that the metabolic control of the influence of $\mathrm{Ca}^{2+}$ on $\mathrm{K}_{\text {(ATP) }}$ channels could be a central factor in glucose regulation of electrical activity. A clue to solve the problem of how the triggering of repolariza- 


\section{H. KITASATO et al.}

tion occurs was found in the effect of removal of extracellular $\mathrm{Ca}^{2+}$ on the pattern of electrical response. At $11.1 \mathrm{~mm}$ of glucose, nominally $\mathrm{Ca}^{2+}$-free solution induced a change in the response pattern from the typical spike-burst type to the continuous spiking type (Fig. 2). Similar pattern change has been reported by Gilon and Henquin [41] who lowered the extracellular $\mathrm{Ca}^{2+}$ concentration from the normal value $(2.5 \mathrm{mM})$ to $1 \mathrm{~mm}$ at $15 \mathrm{~mm}$ of glucose. It is known that there are $\mathrm{Na}^{+} / \mathrm{Ca}^{2+}$-countertransporters in pancreatic $\beta$-cells $[42,43]$. Thus, it may be reasonable to consider that a decrease in $\left[\mathrm{Ca}^{2+}\right]_{\mathrm{i}}$ results in a decrease in $\mathrm{Na}^{+}$influx, leading to a fall in cytosolic $\mathrm{Na}^{+}$concentration, $\left[\mathrm{Na}^{+}\right]_{\mathrm{i}}$, just under the plasma membrane, if $\mathrm{Na}^{+}$ions are continuously extruded by the $\mathrm{Na}^{+}$-pump. The decrease in cytosolic $\mathrm{Na}^{+}$results in the slowing of ATP consumption at $\mathrm{Na}^{+} / \mathrm{K}^{+}$-pump sites. In addition to this finding, lowering the $\mathrm{Na}^{+}$concentration in the $\mathrm{Ca}^{2+}$-free solution to $25 \mathrm{~mm}$ immediately suppressed spike generation and induced slowly progressing depolarization after transient hyperpolarization (lowermost trace in Fig. 2). This finding rules out the possi-

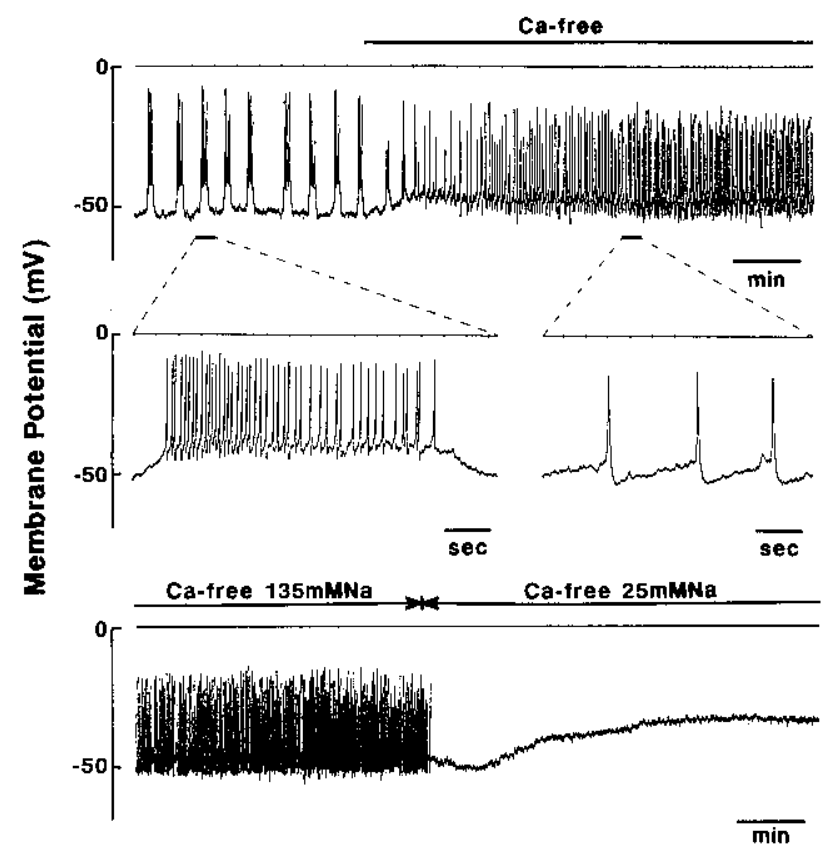

Fig. 2. Effect of $\mathrm{Ca}^{2+}$ removal on electrical activity of the $\boldsymbol{\beta}$-cell. During the period of perifusion with a KRB solution containing $11.1 \mathrm{~mm}$ glucose, $\mathrm{Ca}^{2+}$ concentration was changed from 2.5 to $0 \mathrm{~mm}$ during recording, while $\mathrm{Na}^{+}$concentration was kept at $135 \mathrm{~mm}$ (upper trace). In the middle trace, the details of the portions denoted by bars in the upper trace are shown in 40-fold expanded time scale. The lowermost trace shows a part of the continuous record successive to that shown in the uppermost trace. $\mathrm{Na}^{+}$concentration in the $\mathrm{Ca}^{2+}$-free perifusion solution was lowered to $25 \mathrm{~mm}$ for the period indicated by the bar. Temperature was $36^{\circ} \mathrm{C}$. bility that the depolarization observed when removing extracellular $\mathrm{Ca}^{2+}$ is due to an increase in $\mathrm{Na}^{+}$influx. Under the circumstances where the ATP production rate is kept unchanged, the slowing of ATP consumption should prevent the ATP level from falling, leading to persistent depolarization and continuous spiking [24]. The removal of extracellular $\mathrm{Na}^{+}$from the perifusion solution containing $\mathrm{Ca}^{2+}$ also induced a change in the pattern of electrical activity similar to that caused by the removal of extracellular $\mathrm{Ca}^{2+}$. The substitution of $\mathrm{Na}^{+}$with either Tris, $\mathrm{Li}^{+}$or choline caused persistent depolarization on which spikes were superimposed $[24,44]$. The re-addition of $\mathrm{Na}^{+}$induced a marked and long-lasting silent hyperpolarization that was inhibited by ouabain [44]. Simply adding ouabain to the perifusion solution also caused shortening of the silent period or the complete elimination of the silent phase in a manner depending on its concentration [11]. Furthermore, omitting $\mathrm{K}^{+}$from the perifusion solution had similar effect on the pattern of electrical response as ouabain $[45,46]$. These depolarizing effects have been previously explained as the direct consequence of nonoperation of the electrogenic $\mathrm{Na}^{+} / \mathrm{K}^{+}$-pump. However, the depolarization induced by various means of $\mathrm{Na}^{+} / \mathrm{K}^{+}$-pump inhibition was always accompanied by the suppression of $\mathrm{K}_{(\mathrm{ATP})}$ channel activity [47]. In light of these observations, it may be more rational to deduce that the conditions which cause a fall in ATP consumption always prevent the opening of $\mathrm{K}_{(\mathrm{ATP})}$ channels. In other words, the observed continuation of depolarization is a result of the decrease in ATP consumption. Under physiological conditions, a gradual increase in ATP consumption causes a fall in the ATP/ADT ratio, leading to slight repolarization that is brought about by opening a small fraction of the $\mathrm{K}_{(\mathrm{ATP})}$ channels. It may be said that the slight repolarization resulting from a fall in the ATP/ADP ratio triggers regenerative repolarization through deactivating the voltage-dependent $\mathrm{Ca}^{2+}$ channels. In support of this view, the electrical membrane resistance is lowest at the beginning of the silent phase $[11,25]$.

\section{Oscillation in the ATP/ADP ratio}

During the active phase, intracellular $\mathrm{Ca}^{2+}$ concentration was elevated to about $1 \times 10^{-6} \mathrm{M}$. The amplitude of the spikes elicited on the plateau potential was merely about $20 \mathrm{mV}$, and the capacity of a single $\beta$ cell was about $4.5 \mathrm{pF}\left(d=12 \mu \mathrm{m} ; 1 \mu \mathrm{F} / \mathrm{cm}^{2}\right)$. The minimum charges carried by the influxed $\mathrm{Ca}^{2+}$ ions were calculated to be $90 \times 10^{-15} \mathrm{C} /$ spike $\left(\approx 4.5 \times 10^{-19}\right.$ $\mathrm{mol} / \mathrm{spike}$ ). This amount of $\mathrm{Ca}^{2+}$ caused a concentration change of $4.97 \times 10^{-7} \mathrm{M}$ in a cell with a diameter 
of $12 \mu \mathrm{m}$. On the other hand, taking into account the fact that the peak potential of spikes is about $-20 \mathrm{mV}$, whereas the equilibrium potential of $\mathrm{Ca}^{2+}\left(E_{\mathrm{Ca}}\right)$ is about $110 \mathrm{mV}$, it may be considered that a significant fraction of electric charge carried by the $\mathrm{Ca}^{2+}$ influx is cancelled by outward $\mathrm{K}^{+}$current, suggesting that a larger amount of $\mathrm{Ca}^{2+}$ ions than calculated above flows into a cell during spike generation. However, microfluorometric experiments show that the elevation in $\left[\mathrm{Ca}^{2+}\right]_{\mathrm{i}}$ induced by glucose stimulation is about $1 \times 10^{-6} \mathrm{M}$ at the highest. This calculation implies that a substantial amount of $\mathrm{Ca}^{2+}$ ions are extruded from the cell or taken up by intracellular $\mathrm{Ca}^{2+}$ buffering organelles at a considerably high rate. In nerve fiber, the most potent machinery functioning to extrude $\mathrm{Ca}^{2+}$ is $\mathrm{Na}^{+} / \mathrm{Ca}^{2+}$ exchange [48]. The activation of $\mathrm{Na}^{+} / \mathrm{Ca}^{2+}$ exchange should cause the elevation of intracellular $\mathrm{Na}^{+}$. Although the change in $\mathrm{Na}^{+}$concentration in the compartment just under the plasma membrane is believed to be much higher than the change in bulk cytosol, it is difficult to detect the change in the emission strength of the $\mathrm{Na}^{+}$-sensitive fluorescent probe, SBFI, if the $\mathrm{Na}^{+} / \mathrm{K}^{+}$-pump is working. Indeed, Gilon and Henquin [49] reported that ouabain caused a detectable rise in $\left[\mathrm{Na}^{+}\right]_{i}$ in microfluorometric experiments with SBFI.

Activation of the $\mathrm{Na}^{+} / \mathrm{K}^{+}$-pump is accompanied by the acceleration of ATP consumption. Very recently, oscillation of the ATP/ADP ratio was elegantly demonstrated by Nilsson et al. [50]. They sampled aliquots of islet cells preloaded with fura- 2 before and after adding glucose to the cell suspension at $30 \mathrm{~s}$ intervals while continuously monitoring the cell $\left[\mathrm{Ca}^{2+}\right]_{i}$ in the suspension fluorometrically. Both ATP and ADP were assayed by bioluminescent methods [51]. Using this processs, it became possible to trace the change in the ATP/ADP ratio in connection with the change in $\left[\mathrm{Ca}^{2+}\right]_{\mathrm{i}}$, which reflected the electrical activity during the period of incubation. The experimental results clearly showed that the initial rise in ATP/ADP ratio preceded the initial rise in $\left[\mathrm{Ca}^{2+}\right]_{\mathrm{i}}$, and that at a high concentration of $\mathrm{Ca}^{2+}$ (an additional $5 \mathrm{mM} \mathrm{Ca}^{2+}$ ), oscillation in the ATP/ADP ratio was in accordance with $\left[\mathrm{Ca}^{2+}\right]_{i}$ oscillation; indicating that a rise in the ATP/ADP ratio causes spiking activity and a fall in the ratio terminates spike generation.

Patch-clamp experiments in the cell-attached configuration confirmed that both removing extracellular $\mathrm{Ca}^{2+}$ and lowering extracellular $\mathrm{Na}^{+}$induced suppression of the $\mathrm{K}_{\text {(ATP) }}$ channel activity at $8.4 \mathrm{~mm}$ of glucose [47]. This observation also suggests elevation of the ATP level. Larsson et al. [52] re-examined membrane conductance using the same method used by Smith $e t$ al. [26], and unquestionably demonstrated that membrane conductance was much larger at the beginning of the silent phase as compared to that at the midpoint of the active phase. During the silent phase, intracellular $\mathrm{Ca}^{2+}$ concentration gradually falls, indicating that almost all of the voltage-dependent $\mathrm{Ca}^{2+}$ channels are closed in this period. Electrogenic $\mathrm{Na}^{+} / \mathrm{Ca}^{2+}$ countertransport may contribute to the background inward current to some extent. A leak from the intracellular $\mathrm{Ca}^{2+}$ deposits may maintain the resting $\mathrm{Ca}^{2+}$ level. It is not likely that the non-selective cation channel contributes substantially to the background current because activation of this channel requires $\mathrm{Ca}^{2+}$ concentrations higher than $10^{-4} \mathrm{M}[53]$.

The spike-burst activity observations cited above lead to the following view on periodical spike-burst activity: Elevation of the intracellular $\mathrm{Ca}^{2+}$ level due to spiking activity causes an increase in the $\mathrm{Na}^{+}$influx through activating $\mathrm{Na}^{+} / \mathrm{Ca}^{2+}$-countertransport. The resultant elevation of intracellular $\mathrm{Na}^{+}$accelerates ATP consumption through activation of the $\mathrm{Na}^{+} / \mathrm{K}^{+}$-pump, which causes a fall in the ATP/ADP ratio. Slight repolarization resulting from the opening of a small fraction of $\mathrm{K}_{\text {(ATP) }}$ channels triggers regenerative repolarization, which terminates spiking activity. In the course of the progress of repolarization, a residual fraction of voltage-gated $\mathrm{Ca}^{2+}$ channels are almost completely deactivated. During the silent phase, the intracellular $\mathrm{Ca}^{2+}$ concentration gradually declines, leading to a fall in $\left[\mathrm{Na}^{+}\right]_{\mathrm{i}}$, which causes a gradual rise in the ATP/ADP ratio through decrease in ATP consumption. The gradual rise in the ATP/ADP ratio leads to gradual depolarization back to the threshold of low-threshold $\mathrm{Ca}^{2+}$ channels, of which the opening causes regenerative depolarization underlying the next spike-burst. The $\mathrm{K}_{(\mathrm{ATP})}$ channel has a twofold role: during the silent phase, its gradual closing causes gradual depolarization to the threshold for the plateau potential underlying spiking activity; and during the active phase, its gradual opening triggers regenerative repolarization. The functional coupling of the $\mathrm{Na}^{+} / \mathrm{Ca}^{2+}$-countertransporter and $\mathrm{Na}^{+} / \mathrm{K}^{+}$-pump induces oscillation of the ATP/ADP ratio under conditions where the ATP production rate remains unchanged and voltaged-gated $\mathrm{Ca}^{2+}$ channels are functioning. A part of these conditions is fulfilled by keeping the glucose supply constant.

\section{The Initial Spike-Train}

\section{Response of $\beta$-cells to glucagon}

Single cells in an intact islet always display the initial spike-train and the subsequent spike-burst activity in response to a sudden increase in extracellular glu- 
cose [54], while an isolated single $\beta$-cell does not have the initial spike-train [26]. The mechanism of the initial spike-train preceding cyclic spike-burst activity has not attracted much attention from researchers up to now.

It is known that the amount of glycogen, the main deposits of carbohydrates, in islet cells depends on the extracellular glucose concentration, and that dibutylcAMP reduces the glycogen content, whereas adrenaline increases the level of islet glycogen in the presence of $16.7 \mathrm{~mm}$ glucose [55]. Single pancreatic $\beta$ cells purified by autofluorescence-activated cell-sorting have been reported to release insulin at a rate five times less during nutrient stimulation as compared to intact islets [56]. cAMP levels are low in purified $\beta$ cells, and glucagon induces a rise in the cAMP level [57]. The nutrient-induced insulin release from purified $\beta$-cells is noticeably increased by the addition of either dibutyl-cAMP, glucagon or pancreatic $\alpha$-cells [56]. These findings suggest that the glucagon released from $\alpha$-cells affects the secretory activity of $\beta$ cells lodged in the same islet through elevating the cAMP content of the $\beta$-cells.

Glucagon enhances the glucose-induced electrical response of the $\beta$-cells in intact islets. Upon adding glucagon, the plateau duration increases and the silent phase becomes shorter $[58,59]$. The change in electrical activity may be caused by either activation of the voltage-gated $\mathrm{Ca}^{2+}$ channel or stimulation of the glucose supply. It has been reported that a slowing of the decay and an increase in the peak $\mathrm{Ca}^{2+}$ channel current response to step depolarization is induced by cAMP in both cardiac myocyte and $\beta$-cells $[60,61]$, probably through A-kinase-dependent phosphorylation. On the other hand, the effect of glucagon on the glucose metabolism is well defined in liver cells, stimulating the phosphorolysis of glycogen to yield glucose-1-phosphate [62]. The phosphorylase kinase which activates glycogenphosphorylase is the first enzyme to be established as a cAMP-dependent protein kinase [63].

The fluorescence measurement of endogenous reduced pyridine nucleotides (NAD $(\mathrm{P}) \mathrm{H})$ in isolated islet cells is a good measure of glucose metabolism. Raising the concentration of glucose from 3 to $15 \mathrm{~mm}$ causes an approximate $50 \%$ increase in the autofluorescence, and the mannoheptulose that inhibits glucose phosphorylation [8] causes a marked decrease in the fluorescence [41]. A similar change in NAD(P)H induced by glucose has been reported in single isolated $\beta$-cells [64]. $\mathrm{Ca}^{2+}$-sensitive mitochondrial dehydrogenase is known to stimulate $\mathrm{NAD}(\mathrm{P}) \mathrm{H}$ formation [65]. However, it has been confirmed that $\mathrm{NAD}(\mathrm{P}) \mathrm{H}$ fluorescence increases before $\mathrm{Ca}^{2+}$ entry in response to glucose [66], indicating that an increase in glucose itself is more closely relevant to the increase in $\mathrm{NAD}(\mathrm{P}) \mathrm{H}$ than $\mathrm{Ca}^{2+}$.

At $2.8 \mathrm{mM}$ of glucose, $8.6 \times 10^{-8} \mathrm{M}$ glucagon scarcely affected either NAD $(\mathrm{P}) \mathrm{H}$ or electrical activity (unpublished observation). In contrast, adding glucagon to the perifusion solution containing $11.1 \mathrm{~mm}$ glucose caused a $30 \%$ increase in $\mathrm{NAD}(\mathrm{P}) \mathrm{H}$ in the presence of $2.5 \mathrm{mM} \mathrm{Ca}^{2+}$ (Fig. 3), whereas in the absence of extracellular $\mathrm{Ca}^{2+}$, the addition of glucagon had little effect on $\mathrm{NAD}(\mathrm{P}) \mathrm{H}$ fluorescence [59]. Furthermore, when being stimulated by glucagon containing $11.1 \mathrm{~mm}$ glucose, the removal of extracellular $\mathrm{Ca}^{2+}$ caused NAD(P)H fluorescence decrease gradually until it reached the level attained before glucagon had been added. The resupplementation of $\mathrm{Ca}^{2+}$ restored $\mathrm{NAD}(\mathrm{P}) \mathrm{H}$ fluorescence. All the calmodulin antagonists tested (chlorpromazine, W-7, and trifluoperazine) similarly suppressed the glucagon-stimulated increase in $\mathrm{NAD}(\mathrm{P}) \mathrm{H}$ fluorescence [59]. These observations suggest that cAMP, together with $\mathrm{Ca}^{2+} /$ calmodulin, stimulates $\mathrm{NAD}(\mathbf{P}) \mathrm{H}$ formation even in $\beta$-cells, probably through accelerating the glucose supply from glycogen.

\section{Effect of cAMP on exocytosis}

Studies on permeated $\beta$-cells indicate that cAMP increases insulin release even when $\left[\mathrm{Ca}^{2+}\right]_{\mathrm{i}}$ is held constant [67]. In connection with this, Ämmälä et al. [61] reported that, in whole-cell perforated patchclamp experiments, cAMP caused an increase in $\mathrm{Ca}^{2+}$ current (about $30 \%$ ) to step depolarization with a very large capacitance change (an increase of $175 \%$ ), which means a $175 \%$ increase in the membrane fusion of secretory granules to the plasma membrane. Taking into account the fact that the intracellular trafficking of secretory granules is an ATP-dependent event [68, 69], the very large increase in capacitance change to step depolarization (representing insulin release) induced by CAMP is believed to reflect elevation of the ATP level. In contrast to the effect of cAMP, adrenaline is known to suppress insulin release and electrical activity [70] through stimulation of $\alpha$-adrenoreceptors, and also induce the elevation of islet glycogen content in the presence of $16.7 \mathrm{~mm}$ glucose [55], suggesting that the stimulation of $\alpha$-adrenoreceptors suppresses glucose utilization by activating glycogen synthesis. In fact, clonidine, an $\alpha_{2}$-adrenoreceptor agonist, induces a fall in the ATP/ADP ratio [50]. These findings also support the view that regulation of both the synthesis and breakdown of glycogen is closely related to the control of electrical activity by affecting 


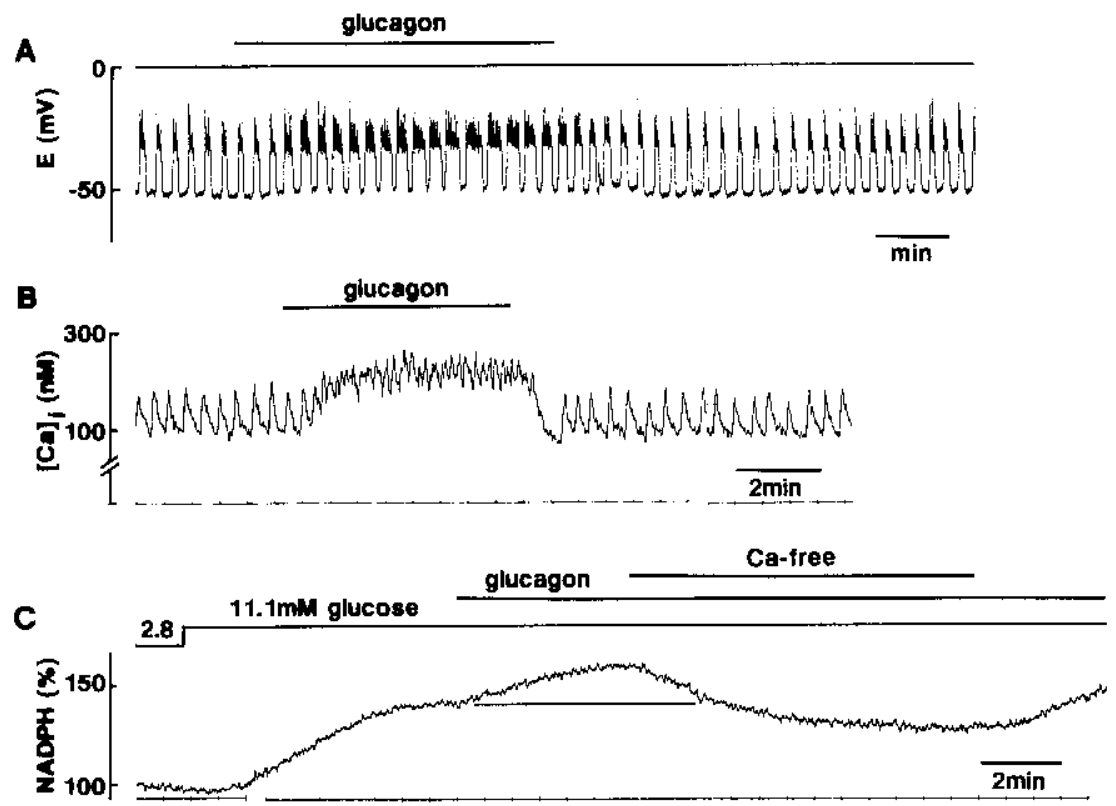

Fig. 3. Glucagon-induced changes of electrical activity, intracellular $\mathrm{Ca}^{2+}$, and the reduced nucleotide fluorescence in $\boldsymbol{\beta}$-cells. A: Electrical activity. Glucose concentration was $11.1 \mathrm{~mm}$. Glucagon $\left(8.6 \times 10^{-8} \mathrm{M}\right)$ was added to the perifusion solution for the period indicated by the bar. Temperature was $36^{\circ} \mathrm{C}$. B: Intracellular $\mathrm{Ca}^{2+}$ concentration. Cell-clusters and single cells were pre-incubated in a Hanks solution containing fura-2/AM for $20 \mathrm{~min}$. Fluorescence intensity of fura-2 was recorded microfluorometrically from a cellcluster consisting of six or seven cells. Glucose concentration was $11.1 \mathrm{~mm}$. Glucagon $\left(8.6 \times 10^{-8} \mathrm{M}\right)$ was added to the

the ATP production rate. It may be too premature to derive any concrete view on the mechanism of the initial spike-train from the data reviewed so far, however, observations in glucagon experiments provide important information for drawing a working model of the initial spike-train.

\section{Biphasic response of insulin release}

It is well known that the phase of the initial spiketrain is in accordance with the first phase of insulinrelease response, and the subsequent period of rhythmical spike-bursts is in accordance with the second phase of secretion response. At present, there is no generally accepted view on the mechanism of this biphasic phenomenon. The integration of data reviewed above allows us to speculate the mechanism as follows.

At low concentrations of glucose, $\alpha$-cells are secreting glucagon, which induces a rise in the cAMP level in $\beta$-cells lodged in the same islet but causes little change in the membrane potential. This is in accordance with the observation that, in a state of low blood glucose, an increased glucagon release from $\alpha$ - perifusion solution for the period indicated by the bar. Temperature was $32^{\circ} \mathrm{C}$. C: Fluorescence intensity of endogenous reduced pyridine nucleotides $(\mathrm{NAD}(\mathrm{P}) \mathrm{H})$. Fluorescence of $(\mathrm{NAD}(\mathrm{P}) \mathrm{H})$ was recorded microfluorometrically from a cell-cluster by a method similar to that of Gilon and Henquin [41]. Glucose concentration was changed from 2.8 to $11.1 \mathrm{~mm}$. Glucagon $\left(8.6 \times 10^{-8} \mathrm{M}\right)$ was added for the period indicated by the bar. During exposure to glucagon, $\mathrm{Ca}^{2+}$ was removed for the period indicated by the bar. Temperature was $32^{\circ} \mathrm{C}$.

cells does not induce elevation of the blood insulin level, and hence does not lead to hypoglycemia but rather maintains the glucose level within the physiological range. When extracellular glucose is raised, the membrane depolarizes to a threshold for the plateau potential on which $\mathrm{Ca}^{2+}$-spikes are superimposed, resulting in the rapid elevation of $\left[\mathrm{Ca}^{2+}\right]_{\mathrm{i}}$. The increased $\left[\mathrm{Ca}^{2+}\right]_{\mathrm{i}}$, together with cAMP, which has already been increased, acts to activate enzymes relevant to glycogenolysis in the $\beta$-cells. The stimulation of glycogenolysis causes a rise in ATP production. As long as the glucose supply from stored glycogen remains elevated, depolarization continues, notwithstanding that spikes are continuously elicited, and the level of $\left[\mathrm{Ca}^{2+}\right]_{i}$ stays so high that acceleration of ATP consumption at the $\mathrm{Na}^{+} / \mathrm{K}^{+}$-pump sites results. On switching to the high-glucose medium, however, the glucagon release from $\alpha$-cells is soon suppressed and, consequently, the cAMP level in the $\beta$-cells falls. The fall in cAMP level is followed by deactivation of the enzymes responsible for the breakdown of glycogen. Under the conditions where ATP consumption is accelerated, a decrease in the glucose supply from stored 


\section{H. KITASATO et al.}

glycogen leads to a fall in the ATP/ADP ratio, which triggers regenerative repolarization. After cessation of the glucose supply from intracellular deposits, glucose influx from the extracellular solution becomes the sole fuel source for ATP synthesis. This period may correspond to the second phase of insulin-secretion response.

\section{Effect of acetylcholine}

Unlike the response to glucagon, $\beta$-cells respond to acetylcholine even at low glucose concentrations [71]. The pattern of response is very similar to that observed when glucose is suddenly increased, consisting of the initial spike-train and subsequent spike-burst $[49,71]$. Muscarinic stimulation increases $\mathrm{Na}^{+}$influx [49]. Thus, acetylcholine-induced depolarization is believed to be due to an increase in the background inward $\mathrm{Na}^{+}$current. An increase in the background inward current means that the electrical response can be elicited at even low concentrations of glucose. When acetylcholine is present in extracellular medium, the ATP/ADP ratio may gradually fall and oscillate in a range relatively lower than that in glu- cose-stimulated cells. This point remains to be verified.

\section{Summary}

The pancreatic $\beta$-cell has four types of $\mathrm{Ca}^{2+}$ channel (L-type, T-type, low-threshold slowly inactivating, and low-threshold non-inactivating $\mathrm{Ca}^{2+}$ ), although the low-threshold non-inactivating $\mathrm{Ca}^{2+}$ channel has not yet been confirmed experimentally. Beside these, there are at least three types of $\mathrm{K}^{+}$channels $\left(\mathrm{K}_{(\mathrm{ATP})}, \mathrm{K}_{(\mathrm{Ca}, \mathrm{V})}\right.$, and $\mathrm{K}_{(\mathrm{V})}$ ), and transporters (GLUT-2, $\mathrm{Na}^{+} / \mathrm{Ca}^{2+}$-countertransporter, and $\mathrm{Na}^{+} / \mathrm{K}^{+}$-pump) as schematically shown in Fig. 4.

Opinions on the mechanism of spike-burst are converging to the following view: At intermediate glucose concentrations, the intracellular ATP/ADP ratio oscillates in the following way. A gradual rise in the ATP/ADP ratio causes gradual progression of depolarization to the threshold for the low-threshold $\mathrm{Ca}^{2+}$ channels, of which the opening causes regenerative depolarization to the plateau potential on which spikes (the L-type $\mathrm{Ca}^{2+}$ channel contributes to spike firing) are superimposed. During the active phase, a fall in

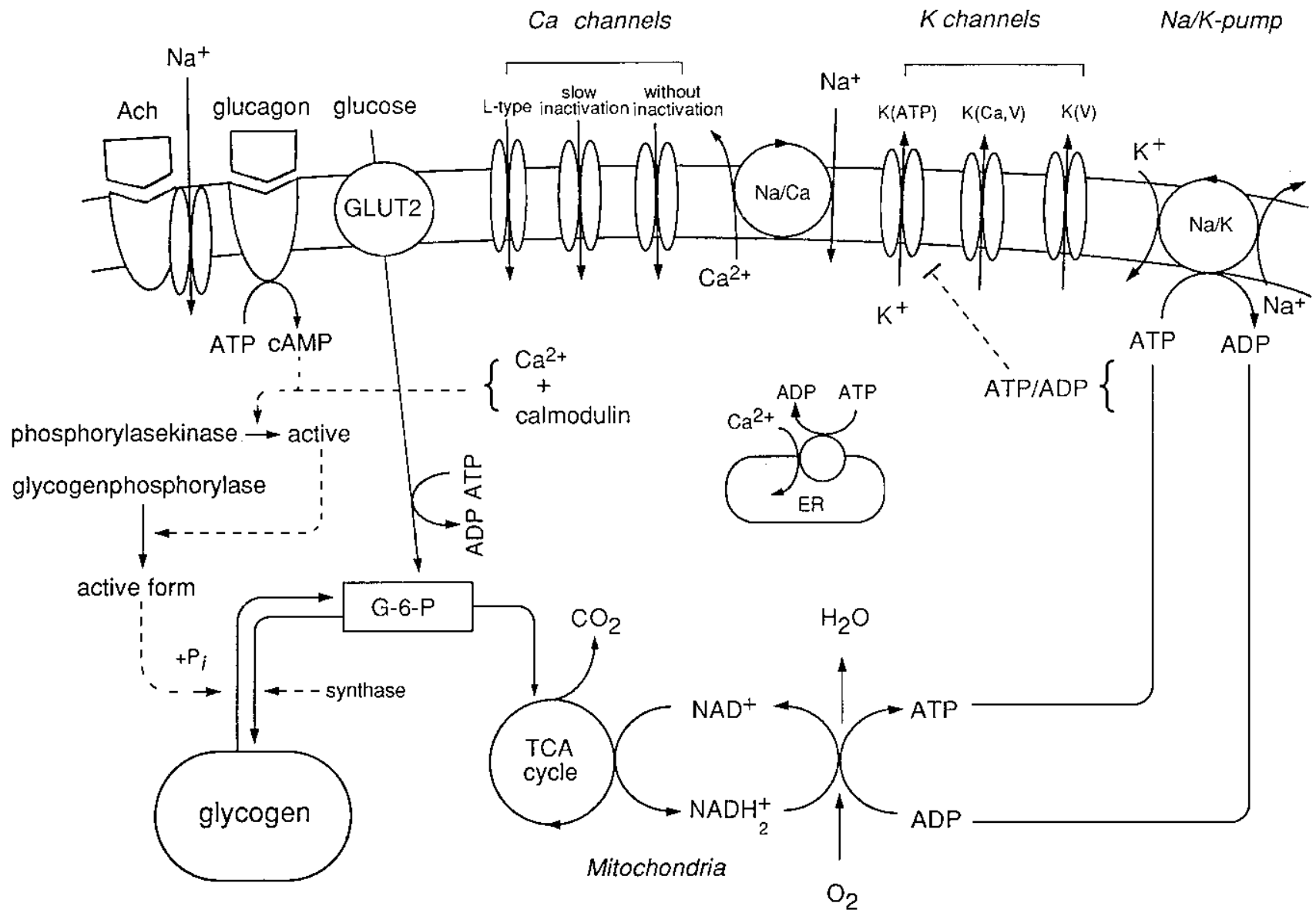

Fig. 4. Schematic drawing of receptors, channels, transporters, and the enzyme systems related to the glucose metabolism. Details are in the text. The T-type $\mathrm{Ca}^{2+}$ channel is not shown. 
the ATP/ADP ratio follows a gradual rise in ATP consumption. Slight repolarization due to the opening of a small fraction of $K_{\text {(ATP) }}$ channels triggers regenerative repolarization. With the progress of repolarization, a residual fraction of voltage-gated $\mathrm{Ca}^{2+}$ channels (low-threshold non-inactivating) are deactivated. During the silent phase, a gradual rise in the ATP/ ADP ratio leads to gradual depolarization back to the threshold for the next spike-burst.

There are still a diversity of views regarding the mechanism of the initial spike-train. On the basis of observations made in various laboratories including ours, we propose the following working model: At low concentrations of glucose, $\alpha$-cells secret glucagon which induces a rise in cAMP in $\beta$-cells lodged in the same islet. A rise in cAMP itself does not activate the enzymes relevant to glycogenolysis, but merely prepares to activate the enzymes. When extracellular glucose increases, $\mathrm{Ca}^{2+}$ spikes are elicited. Influxed $\mathrm{Ca}^{2+}$ ions, together with CAMP, work to activate the enzymes, resulting in an additional supply of fuel for ATP synthesis. After sometime, the cAMP level falls back to a low level and the additional glucose supply from stored glycogen stops. This reaction sequence may be the mechanism behind the initial spike-train. To substantiate this working model, it may be important to elucidate the dependence of the phosphorylasekinase and glycogenphosphorylase activities on the $\mathrm{Ca}^{2+}$ in $\beta$-cells.

\section{REFERENCES}

1. Wollheim CB and Pralong W-F: Cytoplasmic calcium ions and other signalling events in insulin secretion. Biochem Soc Trans 18: 111-114, 1990

2. Santos RM, Rosario LM, Nadal A, Garcia-Sancho J, Soria $\mathrm{B}$, and Valdeolmillos $\mathrm{M}$ : Widespread synchronous $\left[\mathrm{Ca}^{2+}\right]_{i}$ oscillations due to bursting electrical activity in single pancreatic islets. Pflügers Arch 418: 417-422, 1991

3. Hellman B, Gylfe E, Grapengiesser E, Lund P-E, and Berts A: Cytoplasmic $\mathrm{Ca}^{2+}$ osciliations on pancreatic B-cells. Biochim Biophys Acta 1113: 295-305, 1992

4. Bergsten P, Grapengiesser E, Gylfe E, Tenghoim A, and Hellman B: Synchronous oscillations of cytoplasmic $\mathrm{Ca}^{2+}$ and insulin release in glucose-stimulated pancreatic islets. J Biol Chem 269: 8749-8753, 1994

5. Cook DL and Hales CN: Intraceliular ATP directly blocks $\mathrm{K}^{+}$channels in pancreatic B-cells. Nature 311 : 271-273, 1984

6. Orci L, Thorens B, Ravazzola M, and Lodish HF: Localization of the pancreatic beta cell glucose transporter to specific plasma membrane domains. Science 245: 295-297, 1989

7. Tal M, Liang $Y$, Najafi $H$, Lodish $H F$, and Matschinsky FM: Expression and function of GLUT-1 and GLUT-2 glucose transporter isoforms in cells of cultured rat pancreatic islets. J Biol Chem 267: 17241-17247, 1992

8. Ashcroft SJH, Hedeskov CJ, and Randle PJ: Glucose metabolism in mouse pancreatic islets. Biochem $\mathrm{J} 118$ : 143-154, 1970

9. Ashcroft FM, Ashcroft SJH, and Harrison DE: Properties of single potassium channels modulated by glucose in rat pancreatic B-cells. J Physiol (Lond) 400: $501-527,1988$

10. Atwater I, Dawson CM, Ribalet B, and Rojas E: Potassium permeability activated by intracellular calcium ion concentration in the pancreatic B-cell. J Physiol (Lond) 288: 575-588, 1979

11. Ribalet $\mathrm{B}$ and Beigelman PM: Cyclic variation of $\mathrm{K}^{+}$ conductance in pancreatic B-cells: $\mathrm{Ca}^{2+}$ and voltage dependence. Am J Physiol 237: C137-C146, 1979

12. Cook DL, Ikeuchi M, and Fujimoto W: Lowering of $\mathrm{pH}$ inhibits $\mathrm{Ca}^{2+}$-activated $\mathrm{K}^{+}$channels in pancreatic $\mathrm{B}$ cells. Nature 311: 269-271, 1984

13. Kukuljan $M$, Goncalves $A A$, and Atwater I: Charybdotoxin-sensitive $\mathrm{K}_{(\mathrm{Ca})}$ channel is not involved in glucoseinduced electrical activity in pancreatic B-cells. J Membr Biol 119: 187-195, 1991

14. Hermans MP and Henquin J-C: Relative importance of extracellular and intracellular $\mathrm{Ca}^{2+}$ for acetylcholine stimulation of insulin release in mouse islets. Diabetes 38: 198-204, 1989

15. Valdeolmillos M, Santos RM, Contreas D, Soria B, and Rosário LM: Glucose-induced oscillations of intracellular $\mathrm{Ca}^{2+}$ concentration resembling bursting electrical activity in single mouse islets of Langerhans. FEBS Lett 259: 19-23, 1990

16. Cook DL, Satin LS, and Hopkins WF: Pancreatic B cells are bursting, but how? Trends Neurosci 14: 411-414 1991

17. Rosário LM, Barbosa RM, Antunes CM, Silva AM, Abrunhosa AJ, and Santos RM: Bursting electrical activity in pancreatic $\beta$-cells: Evidence that the channel underlying the burst is sensitive to $\mathrm{Ca}^{2+}$ influx through L-type $\mathrm{Ca}^{2+}$ channels. Pflügers Arch 424: 439-447, 1993

18. Worley III JF, Mclntyre MS, Spencer B, Mertz RJ, Roe MW, and Dukes ID: Endoplasmic reticulum calcium store regulates membrane potential in mouse islet $\beta$ cells. J Biol Chem 269: 14359-14362, 1994

19. Henquin J-C and Meissner HP: Significance of ionic fluxes and changes in membrane potential for stimulus-secretion coupling in pancreatic B-cells. Experientia 40: 1043-1052, 1984

20. Ashcroft FM: Adenosine 5'-triphosphate-sensitive potassium channels. Annu Rev Neurosci 11: 97-118, 1988

21. Cook DL, Satin LS, Ashford MLJ, and Hales CN: ATPsensitive $\mathrm{K}^{+}$channels in pancreatic $\beta$-cells: Sparechannel hypothesis. Diabetes 37: 495-498, 1988

22. Henquin $\mathrm{J}-\mathrm{C}$ : Glucose-induced electrical activity in $\beta$ celis. Feedback control of ATP-sensitive $\mathrm{K}^{+}$channels by $\mathrm{Ca}^{2+}$ ? Diabetes 39: 1457-1460, 1990

23. Grynkewiz $G$, Poenie M, and Tsien RY: Generation of $\mathrm{Ca}^{2+}$ indicators with greatly improved fluorescence properties. J Biol Chem 260: 3440-3450, 1985

24. Hattori $M, K a i ~ R$, and Kitasato $H$ : Effects of lowering external $\mathrm{Na}^{+}$concentration on cytoplasmic $\mathrm{pH}$ and $\mathrm{Ca}^{2+}$ 


\section{H. KITASATO et al.}

concentration in mouse pancreatic $\beta$-cells: Mechanism of periodicity of spike-bursts. Jpn J Physiol 44: 283293, 1995

25. Atwater 1, Pibalet B, and Rojas E: Cyclic changes in potential and resistance of the $\beta$-cell membrane induced by glucose in islets of Langerhans from mouse. J Physiol (Lond) 278: 117-139, 1978

26. Smith PA, Ashcroft FM, and Rorsman P: Simultaneous recordings of glucose dependent electrical activity and ATP-regulated $\mathrm{K}^{+}$-currents in isolated mouse pancreatic $\beta$-cells. FEBS Lett 261: 187-190, 1990

27. Cook DL, Crill WE, and Porte DJ: Plateau potentials in pancreatic islet cells are voltage-dependent action potentials. Nature 286: 404-406, 1980

28. Satin LS and Cook DL: Evidence for two calcium currents in insulin-secreting cells. Pflügers Arch 411: 401409, 1988

29. Satin LS and Cook DL: Calcium current inactivation in insulin-secreting cells is mediated by calcium influx and membrane depolarization. Pflügers Arch 414: $1-10,1989$

30. Rorsman $P$ and Trube G: Calcium and delayed potassium currents in mouse pancreatic B-cells under voltage-clamp conditions. J Physiol (Lond) 374: 531-550, 1986

31. Hopkins WF, Satin LS, and Cook DL: Inactivation kinetics and pharmacology distinguish two calcium currents in mouse pancreatic B-cells. J Membr Biol 119: 229239, 1991

32. Ashcroft FM, Kelly RP, and Smith PA: Two types of $\mathrm{Ca}$ channel in rat pancreatic $\beta$-cells. Pflügers Arch 415: 504-506, 1990

33. Plant TD: Properties and calcium-dependent inactivation of calcium currents in cultured mouse pancreatic B-cells. J Physiol (Lond) 404: 731-747, 1988

34. Keizer $J$ and Smolen P: Bursting electrical activity in pancreatic $\beta$ cells caused by $\mathrm{Ca}^{2+}$ - and voltage-inactivated $\mathrm{Ca}^{2+}$ channels. Proc Natl Acad Sci USA 88: 3897-3901, 1991

35. Henquin J-C and Meissner HP: Opposite effects of tolbutamide and diazoxide on ${ }^{86} \mathrm{Rb}^{+}$fluxes and membrane potential in pancreatic B cells. Biochem Pharmacol 31: 1407-1415, 1982

36. Cook DL and Ikeuchi M: Tolbutamide as mimic of glucose on B-cell electrical activity. Diabetes 38: 416-421, 1989

37. Philipson LH and Steiner DF: Pas de Deux or More: The sulfonylurea receptor and $\mathrm{K}^{+}$channels. Science 268: 372-373, 1995

38. Sturgess NC, Ashford MLJ, Cook DL, and Hales CN: The sulfonylurea receptor may be an ATP-sensitive potassium channel. Lancet 8453: 474-475, 1985

39. Aguilar-Bryan L, Nichols CG, Rajan AS, Parker C, and Bryan J: Co-expression of sulfonylurea receptors and $\mathrm{K}_{\text {ATP }}$ channels in hamster insulinoma tumor (HIT) cells. Evidence for direct association of the receptor with the channel. J Biol Chem 267: 14934-14940, 1992

40. Inagaki N, Gonoi T, Clement IV JP, Namba N, Inazawa J, Gonzalez G, Aguilar-Bryan L, Seino S, and Bryan J: Reconstitution of IKATP: An inward rectifier subunit plus the sulfonylurea receptor. Science 270: 11661170,1995
41. Gilon $P$ and Henquin J-C: Influence of membrane potential changes on cytoplasmic $\mathrm{Ca}^{2+}$ concentration in an electrically excitable cell, the insulin-secreting pancreatic B-cell. J Biol Chem 267: 20713-20720, 1992

42. Herchuelz A, Sener A, and Malaisse WJ: Regulation of calcium flux in rat pancreatic islets: Calcium extrusion by sodium-calcium countertransport. $\rfloor$ Membr Biol 57 : $1-12,1980$

43. Plasman PO, Lebrun P, and Herchuelz A: Characterization of the process of sodium-calcium exchange in pancreatic islet cells. Am J Physiol 259: E844-E850, 1990

44. deMiguel $R$, Tamagawa $T$, Schmeer $W$, Nenquin $M$, and Henquin JC: Effects of acute sodium omission on insulin release, ionic flux and membrane potential in mouse pancreatic B-cells. Biochim Biophys Acta 969 : 198-207, 1988

45. Meissner HP: Electrical characteristics of the beta-cells in pancreatic islets. J Physiol (Paris) 72: 757-762,1976

46. Henquin J-C and Meissner HP: The electrogenic sodium-potassium pump of mouse pancreatic B-cells. J Physiol (Lond) 332: 529-552, 1982

47. Ding $W-G$, He L-P, Omatsu-Kanbe $M$, and Kitasato $H$ : A possible role of the ATP-sensitive potassium ion channel in determining the duration of spike-burst in mouse pancreatic $\beta$-cells. Biochim Biophys Acta 1279: 219 226, 1996

48. Blaustein MP and Nelson MT: Sodium-calcium exchange: its role in the regulation of cell calcium. Membrane transport of calcium. In: Membrane Transport of Calcium, ed. Carafoli E, Academic Press, London, pp 217-236, 1982

49. Gilon $P$ and Henquin JC: Activation of muscarinic receptors increases the concentration of free $\mathrm{Na}^{+}$in mouse pancreatic B-cells. FEBS Lett 315: 353-356, 1993

50. Nilsson $T$, Schultz V, Berggren P-O, Corkey BE, and Tornheim K: Temporal patterns of changes in ATP/ADP ratio, glucose 6-phosphate and cytoplasmic free $\mathrm{Ca}^{2+}$ in glucose-Stimulated pancreatic $\beta$-cells. Biochem $\mathrm{J}$ 314: $91-94,1996$

51. Schultz V, Sussman I, Bokvist K, and Tornheim K: Bioluminometric assay of ADP and ATP at high ATP/ADP ratios: Assay of ADP after enzymatic removal of ATP. Anal Biochem 215: 302-304, 1993

52. Larsson $\mathrm{O}$, Kindmark $\mathrm{H}$, Bränström R, Fredholm $\mathrm{B}$, and Berggren $\mathrm{P}-\mathrm{O}$ : Oscillations in $\mathrm{K}_{\text {ATP }}$ channel activity promote oscillations in cytoplasmic free $\mathrm{Ca}^{2+}$ concentration in the pancreatic $\beta$ cell. Proc Natl Acad Sci USA 93: 5161-5165, 1996

53. Sturgess NC, Hales $C N$, and Ashford MLJ: Calcium and ATP regulate the activity of a non-selective cation channel in rat insulinoma cell line. Pflügers Arch 409: $607-615,1987$

54. Henquin JC and Meissner HP: Significance of ionic fluxes and changes in membrane potential for stimulus-secretion coupling in pancreatic B-cells. Experientia 40: 1043-1052, 1984

55. Idahl L-A and Hellman B: Regulation of pancreatic $\beta$ cell glycogen through cyclic-3,5-AMP. Diabetologia 7: 139-142, 1971

56. Pipeleers DG, Schuit FC, In't Veld PA, Maes E, 
Hooghe-Peters EL, Van De Winkel M, and Gepts W: interplay of nutrients and hormones in the regulation of insulin release. Endocrinology 117: 824-833, 1985

57. Schuit FC and Pipeleers DG: Regulation of adenosine $3^{\prime}, 5^{\prime}$-monophosphate levels in the pancreatic B cell. Endocrinology 117: 834-840, 1985

58. Ikeuchi $M$ and Cook DL: Glucagon and forskolin have dual effects upon islet cell electrical activity. Life Sci 35: 685-691, 1984

59. He L-P and Kitasato $\mathrm{H}$ : Glucagon induces $\mathrm{Ca}^{2+-}$-dependent increase of reduced pyridine nucleotides in mouse pancreatic $\beta$-cells. Biochim Biophys Acta 1310: 325-333, 1996

60. Tiaho F, Richard S, Lory P, Nerbonne JM, and Nargeot $\mathrm{J}$ : Cyclic-AMP-dependent phosphorylation modulates the stereospecific activation of cardiac $\mathrm{Ca}$ channels by Bay K 8644. Pflügers Arch 417: 58-66, 1990

61. Ämmälä C, Ashcroft FM, and Rorsman P: Calcium-independent potentiation of insulin release by cyclic AMP in single $\beta$-cells. Nature 363: 356-358, 1993

62. Pillkis SJ, El-Maghrabi MR, and Claus TH: Hormona regulation of hapatic gluconeogenesis and glycolysis. Annu Rev Biochem 246: 1872-1876, 1971

63. Cohen P: Protein phosphorylation and hormone action. Proc R Soc Lond(Biol) 234: 115-144, 1988

64. Praiong $W-F$, Spät $A$, and Wollheim CB: Dynamic pacing of cell metabolism by intracellular $\mathrm{Ca}^{2+}$ transients. J Biol Chem 269: 27310-27314, 1994
65. McCormack JG, Halestrap AP, and Denton RM: Role of calcium ions in regulation of mammalian intramitochondrial metabolism. Physiol Rev 70: 391-425, 1990

66. Pralong W-F, Bartley $C$, and Woltheim CB: Single islet $\beta$-cell stimulation by nutrients: Relationship between pyridine nucleotides, cytosolic $\mathrm{Ca}^{2+}$ and secretion. EMBO J 9: 53-60, 1990

67. Jones PM, Persaud SJ, and Howell SL: $\mathrm{Ca}^{2+}$-induced insulin secretion from electrically permeabilized islets. Loss of the $\mathrm{Ca}^{2+}$-induced secretory response is accompanied by loss of $\mathrm{Ca}^{2+}$-induced protein phosphorylation. Biochem J 285: 973-978, 1992

68. Arvan $P$ and Castle D: Protein sorting and secretion granule formation in regulated secretory cells. Trends Cell 2: 327-331, 1992

69. Sollner T, Whiteheart SW, Brunner M, Erdument-Bromage $H$, Geromanos $S$, Tempst $P$, and Rotheman JE: SNAP receptors implicated in vesicle targeting and fusion. Nature 362: 318-324, 1993

70. Debuyser A, Drew G, and Henquin J-C: Adrenaline inhibition of the $B$ cell membrane. Pflügers Arch 419: 131-137, 1991

71. Henquin JC, Garcia M-C, Bozem M, Hermans MP, and Nenquin $M$ : Muscarinic control of pancreatic $B$ cell function involves sodium-dependent depolarization and calcium influx. Endocrinology 122: 2134-2142, 1988 